\title{
Talent Identification of Future Sportsmen Using Sport Search Application
}

\author{
I Gede Dharma Utamayasa \\ Universitas PGRI Adi Buana Surabaya, Indonesia \\ dharmautamayasa@unipasby.ac.id
}

\begin{abstract}
Sports coaching is a very important factor for advancing the world of sports. Without properly systemized scouting, the achievement stage will not be maximally achieved. This research aims to identify the sports talents of students at Wonorejo I/312 Primary School Surabaya and the dominant sports among the students. This quantitative research employed exploratory descriptive method. The research population included ten 6th grade students. Data obtained using 10 test types from Sport Search Aussie Sport Australia were identified and analysed. Based on the ranks, the results revealed the following sports talents: Diving, Gymnastics, Weightlifting, Indoor Cricket, and Powerlifting, which can potentially be developed.
\end{abstract}

Keywords

talent identification;

sportsmen; sport search

\section{Introduction}

The systems models and programmes designed to identify and provide for the development of talented young people in sport continue to evolve in their complexity and comprehensive, often driven by national interests of doing well in sport (Abstracts 220, 2010). The development of sports is driven by sports coaching and scouting. The performance of sports is determined by two main factors: (1) the internal factors of athletes, including physical condition, intelligence, psychomotor and affective abilities; (2) the external factors of athletes, such as supporting factors, trainers, parental support, availability of infrastructure, training programs, research results, work or school environment, community and other external factors (Hadi et al., 2019). The development of sports is influenced by a good coaching system with a strong foundation. Sports coaching is a very important stage in fostering sports achievement. The development of sports achievement in Indonesia, which is followed by sports coaching in the form of a cone at the bottom, where early childhood development is at the bottom, followed by specialization, and achievement. A sports talent involves a complex set of skills that are at the same time genetically determined, dependent on environmental conditions and are difficult to be measured with the satisfactory level of accuracy (Dey \& Dey, 2012).

It goes without saying that talent identification attracted a considerable amount of attention in the last decade (Buekers et al., 2015). The achievement of national sports are far behind compared to other ASIA countries. A very big problem for the nation is increasing achievement. The improvement of our sports performance is slower than the countries of China, Japan, Korea, Thailand and even Vietnam. This lag in sports achievement encourages the need for an arrangement with a national sports coaching system including a system of scouting and developing talented athletes. Guiding the development of talented athletes in developing and developed countries, their achievements are supported by adequate resources, government funds and expertise through scientific and inter-disciplinary approaches. The Indonesian people who like to 
exercise are very much, therefore it is necessary to have trainers and sports practitioners to follow up with special guidance for gifted children to create high achieving young athletes with a long period of time. Lawrence (2010) described the reasons for developing gifted identification is felt by many governments as a means to utilize the nation's sporting talents, to bring future success in the international arena.

In sports coaching for prospective athletes, especially children, the main factor that must be considered is developing their talents, starting with providing them with various basic skills (Hadi et al., 2019). Early childhood coaching for 6 to 16 years old is part of the national policy. Excellent athletes have good anthropometric and psychological characteristics. Limoochi reported, based on the views of 40 international coaches, $36 \%$ antropometri is the most important factor for identifying talents, followed by psychological factor 33\% and psychomotor factor 25\% (Faber et al., 2011). There are still many sports that have not achieved the desired results and always have problem is that it is difficult to find talented athletes. There are still many sports that have not achieved the desired results and always have problem is that it is difficult to find talented athletes (Vaeyens et al., 2008). One way to get talented athletes is to do talent scouting from an early age. It is advocated that talent identification and development programmes should be dynamic and interconnected taking into consideration maturity status and the potential to develop rather than to exclude children at an early age. (Vaeyens et al., 2008) Sports, especially at the school level, need special attention from professional coaches and coaches. Through coaching and training for students to make athletes who are talented and have the potential for the future as a form of athlete regeneration. As such, talent identification appears to be a paramount ingredient in a team's long term success (Gee et al., 2010).

Sport and search method can be employed for identifying the sport talents of children in accordance with their potentials and characteristics. Sport and search application was made by AUSIC (Australia Sport Commision), which is one of the references adopted by KONI - The National Sports Committeeof Indonesia. The method can measure the potentials of children, which include 10 items: 1) height, 2) sitting height (portion), 3) body weight, 4) arm span width, 5) ability to throw and catch a tennis ball, 6) ability to throw a basketball, 7) vertical jumping height, 8) running agility, 9) 40 metre sprint, and 10) multistage fitness test. The test is easy to do and only requires simple tools. The results obtained can be analysed using a computer. The goal of a talent identification decision is to correctly identify a developing athlete with the potential to become a successful elite performer in their respective sport (Till \& Baker, 2020).

Talent recognition is nothing new in sport. In the 60s and 70s almost all Eastern European countries developed specific methods for potential athletes. While talent identification is a difficult and often inaccurate process, a further challenge is that most sports implement talent identification processes within cohorts of young athletes (Till \& Baker, 2020). The development of sports talents can be seen as a process where coaches help athletes realize their full potentials (Michael et al., 2014). Based on the definitions, talent can be understood as the special ability of individuals to achieve something in sports, especially when the athletes are trained continuously so that they can make achievements in the future. However, sports coaching does not start from specialization or talent scouting, making the results less optimal (Hadi \& Semarang, 2019). In sports, it is important to find students with special talents, especially to get young athletes by observing and encouraging them to make achievements. Talents in sports is determined by genetic morphology, psychomotor and functional abilities, cognitive and social characteristics, and motivation (Žvan \& Čoh, 2018). Therefore, it is of interest to further investigate this underrepresented area in the talent identification literature to gain a better 
understanding of the possible attributes and strategies used recruiters when identifiying potentially talented players (Larkin \& O'Connor, 2017).

Elementary school Wonorejo 1/31 Surabaya needs special attention and guidance for sports. This type of choaching pattern must be immediately addressed and corrected to achieve maximum results. Choaches and experts in sports are trying to help correct this imperfect. The step is a talent scouting to find athletes who are in the field of sports. Elementary school Wonorejo 1/31 Surabaya has not yet applied the method of scouting talent in the sports field. The coaches should follow developments in the field of sports so that they have an understanding to find the of athletes who can later achieve achievements. This method is not widely known among teachers or sport supervision. The results obtained form the talent scouting are expected to have special and specific choaching and training to produce outstanding athletes from Elementary school Wonorejo 1/31 Surabaya. One of the strategies which can be applied is by using Sport search based on the right procedures. The application was used to address the talent scouting problems of young athletes. The use has considered the technology of sport search which has been adopted by KONI and the Ministry of Youth and Sports in the coaching of young athletes.

\section{Review of Literatures}

Choach for young children in each sport will be realized from the beginning of the choaching itself. Elementary school children are suitable in sports coaching efforts because at this time they have a lot of time and opputunity that is long enough to achieve maximum achievement. A person must require special choaching and training to achieve the desired achievements. The search for a young sports teacher is one of the tasks of a sport teacher and coach. Talent identification programmes are designed to identify young athletes who possess extraordinary potential for success in senior elite sport, and to select and recruit them into talent promotion programmes (Vaeyens et al., 2009). If a child achieves high achievement in each sports field, from an early age the child concerned is directed to pursue these sports activities. The identification of talented athletes should be a concern of every sport. Identification of talents is very important to: 1 ) find talented athletes; 2) select early age athletes; 3 ) monitor them continuously; and 4) help aspiring athletes achieve the highest mastery. Talent in sports is a combination of above-average biomotor skills, creativity and motivation (Malina, 2010). This condition in the identification of talents is very important. This is intended to produce athletes who are truly competent in their fields. All children can learn in a certain field and succeed, but without talent, it is difficult for them to reach the top.

Other well-known identification and selection methods are as follows (Cha et al., 2014):

- Talent identification and development program in sports (TIDPS)

- Talent intelligence, personality, skills (TIPS)

- Speed, understanding and personality (SUPS)

- Talent differentiation model (DMGT)

- Talent (SLO)

Indication of giftedness of sportsmen must be carried out by measuring objectively. Talent identification in sports can be seen based on the purpose of the identification or selection process: identifying and choosing for the present (live performance) versus identifying and choosing for the future (prediction) (Roberts et al., 2019). The main objective of talent identification is selecting prospective athletes who have the highest abilities in a particular sport. Specialization starts with the environment, coaches and 
parents to achieve extraordinary results (Žvan \& Čoh, 2018). The earlier a child demonstrates training compliance with the ability to learn, the more successful he or she completes the training program. The time to train before reaching peak achievement age will have a positive effect on training.

\section{Research Methods}

This quantitative method employed exploratory descriptive method. Determination of the area used in this study is purposive sampling, wich means that the writer determines directly the research area with the aim of providing accurate data. The research population included ten 6th grade students from Wonorejo I/312 Primary School Surabaya. The samples were taken from the whole population.

\section{Discussion}

This sections presents the research data obtained from the test and measurement conducted with 10 items from the sport and search, iterated based on the identification of talents and interests of the students. The data were analysed using a computer with Soil Wear software in sport search. Data from the ten students were considered adequate for further analysis.

Table 1. Results of Analysis based on Ranks

\begin{tabular}{lll}
\hline Ranks & Data from Sport Search & Number \\
\hline I & Diving & 9 \\
II & Gymnastics & 8 \\
III & Weightlifting & 5 \\
IV & Indoor Cricket & 4 \\
V & Powerlifting & 2 \\
\hline
\end{tabular}

Based on the analysis, 9 students have a potential in diving, 8 students in gymnastics, 5 students in weightlifting, 4 students in indoor cricket, and 2 students in powerlifting. Therefore, those sports can potentially be developed. Basically all students are gifted to achieve sports achievements. Each individual has the factors needed in each sport, it's just that the provision of different training proxies and different intensities. Students are said to be sporting talent in that there are characteristics that can be developed towards success in achieving higer achievements. In elite sporting codes, the identification of future athletes into specialized talent pathways is heavily reliant upon objective physical, technical, and tactical characteristics, in addition to subjective coach assessments (Jacob et al., 2018).

It is hoped that sports choaching that is carried out systematically, diligently and sustainably the desired achievements. Sport choaching in early childhood will be realized in the initial process of sports choaching starting from choaching athletes by scouting talents at an earl age. Making achievements require systematic planning and continuous implementation from coaching to the highest level, making achievements (Hadi \& Semarang, 2019). Comprehensive talent identification is not only done once, but over several years so that athletes are ready to be developed in various sports, to make high achievements, both at the regional, national and international levels. Early childhood coaching is a long-term process whose goal is to produce high-achieving athletes. Creating athletes requires a long time, until the athletes can reach the peak of achievement. Ratno \& Nidyatama (2019) explained that sports choaching to produce high-achieving a long period 
of time and appropriate training methods. Parmbudi (2017) the identification of giftedness in a sport is a way that can be done to identify the potential in a particular sport, so that the identified talents of children can be channeled into sports achievements.

Athlete detection and identification is critical to the athlete development process, as they typically guide the initial, and subsequent, selection of athletes into development programs (Jacob et al., 2018). Handling of sports choaching requires competent and qualified experts in the field of sports, namely: experts in the field of sport, experts in the field of sports healt, experts in the field of sports psychology and other experts who are suitable for coaching. Planning that is well developed, if supported and grown in a good coaching system. Talent identification is done determine potential children in one sport according to their talents. The process of sports coaching to achieve maximum performance is not a simple, it needs a long process. The training system carried out must be systematically based on methods based on science and technology. This study has identified talents using a system-based talent program.

\section{Conclusion}

Talent detection is a very intriguing and inspiring endeavour but also one with a considerable responsibility as those who are involved in this process are shaping the dreams of many youngsters (Buekers et al., 2015). This research has presented the results of talent identification using a computer program based on the anthropometric and physical data of the students. This brings us to the final observation, namely that talent detection is useless without a strong program to develop the available competences (Buekers et al., 2015). The participants of the study were ten 6th grade students of Wonorejo I/312 Primary School Surabaya. Further research should conduct the identification process as effective as possible so that coaching can run smoothly. Also, the number of students and schools can be increased, and more previous studies can be included in the literature review.

\section{References}

Abstracts 220. (2010). 44(Suppl I), 2010.

Buekers, M., Borry, P., \& Rowe, P. (2015). Talent in sports. Some reflections about the search for future champions. Movement and Sports Sciences - Science et Motricite, 12(88), 3-12. https://doi.org/10.1051/sm/2014002

Cha, T., Sport, Y., \& Risks, H. (2014). Zna čil no sti tek mo val ne ga špor ta otrok in mla dost ni kov ter neka te ra zdravs tve na tve ga nja mla dih v to vrst nem špor tu. 53(4), 565-583.

Dey, S., \& Dey, S. (2012). Identification of Talent in Sports. A Textbook of Sports and Exercise Physiology, 247-247. https://doi.org/10.5005/jp/books/11694_13

Faber, I., Osterveld, F., \& Nijhuis-Van der Sanden, R. (2011). A first step to an evidencebased talent identification program in the Netherlands; a research proposal. ITTF Sport Science Congress, 15, 15-18. http://69.20.231.204/ittf_science/SSCenter/docs/04-42 Faber.pdf

Gee, C. J., Marshall, J. C., King, J. F., \& Management, S. (2010). Should coaches use personality assessments in the talent identification process? A 15 year predictive study on professional hockey players. 4(1), 1-10. 
Hadi, Haryono, S., Romadhoni, S., \& Retno, E. S. (2019). The Potential Achievement of Weightlifting Sport in Semarang Through Talent Identification. 362(3), 152-156. https://doi.org/10.2991/acpes-19.2019.33

Hadi, R., \& Semarang, U. N. (2019). The Identification Of Sports Talent In Male Students Of Junior High School In Semarang City. 362(Acpes), 112-115.

Jacob, Y., Spiteri, T., Hart, N., \& Anderton, R. (2018). The Potential Role of Genetic Markers in Talent Identification and Athlete Assessment in Elite Sport. Sports, 6(3), 88. https://doi.org/10.3390/sports6030088

Larkin, P., \& O'Connor, D. (2017). Talent identification and recruitment in youth soccer: Recruiter's perceptions of the key attributes for player recruitment. PLoS ONE, 12(4), 1-15. https://doi.org/10.1371/journal.pone.0175716

Malina, R. M. (2010). Early sport specialization: Roots, effectiveness, risks. Current Sports Medicine Reports, 9(6), 364-371. https://doi.org/10.1249/JSR.0b013e3181fe3166

Michael, A., Joseph, A., \& Olufemi, O. (2014). Designing Template for Talent Identification and Development in Sport. 7(1), 128-132. https://doi.org/10.3968/4252

Pambudi, P.S. (2017). Identifikasi Tingkat Keberbakatan Cabang Olahraga Pada Siswa Usia 12-13 Tahun SMP Negeri 2 Galagah Suku Using Kabupaten Banyuwangi Tahun Pelajaran 2016/2017. Jurnal Kejaora, 2(1), 90-95

Ratno, P., \& Nidyatama, N. (2019). Analisis Hasil Talent Scouting Dispora Kota Medan Cabang Olahraga Karate Pada Calon Atlet PPLD Kota Medan. Sains Olahraga: Jurnal Ilmiah Ilmu Keolahrgaan. https://doi.org/10.24114/so.v3i1.13060

Roberts, A. H., Greenwood, D. A., Stanley, M., Humberstone, C., Iredale, F., \& Raynor, A. (2019). Coach knowledge in talent identification: A systematic review and metasynthesis. Journal of Science and Medicine in Sport, 22(10), 1163-1172. https://doi.org/10.1016/j.jsams.2019.05.008

Till, K., \& Baker, J. (2020). Challenges and [Possible] Solutions to Optimizing Talent Identification and Development in Sport. Frontiers in Psychology, 11. https://doi.org/10.3389/fpsyg.2020.00664

Vaeyens, R., Güllich, A., Warr, C. R., \& Philippaerts, R. (2009). Talent identification and promotion programmes of olympic athletes. Journal of Sports Sciences, 27(13), 1367-1380. https://doi.org/10.1080/02640410903110974

Vaeyens, R., Lenoir, M., Williams, A. M., \& Philippaerts, R. M. (2008). Talent identification and development programmes in sport: Current models and future directions. Sports Medicine, 38(9), 703-714. https://doi.org/10.2165/00007256200838090-00001

Žvan, M., \& Čoh, M. (2018). Identification of young talents in sport. Glasnik Antropoloskog Drustva Srbije, 53(53), 119-123. https://doi.org/10.5937/gads5318642 